\title{
| Game of genomes: to be continued
}

\author{
Kristina A. Zakurdaeva \\ Foundation for Cancer Research Support (RakFond), Moscow, Russia \\ Dr. Kristina A. Zakurdaeva, Foundation for Cancer Research \\ E-mail: christina@rakfond.org \\ Support (RakFond), 15 Rochdelskaya St., bld. 17-18, room III, \\ 123022, Moscow, Russia
}

Citation: : Zakurdaeva KA. Game of genomes: to be continued. Cell Ther Transplant 2019; 8(4): 91-93.

\section{Summary}

The landscape of genome editing has dramatically changed over the recent five years, and evolved from scientific ideas and laboratory research to multiple clinical applications changing patients' lives, creating new commercial opportunities with substantial investments in the field and notable deals, and societal dilemmas raising many discussion items for the medical community and general public. Today, many of the cutting-edge $\mathrm{R} \& \mathrm{D}$ efforts, investments, regulatory initiatives, and ethical discussions occur in this field. In what way can the market and society keep up with the latest scientific discoveries, and what is the next big thing to come?
In this essay, I will discuss the opportunities and challenges of current cell and gene therapy market, recent approvals and their clinical and economic impact, novel technologies that are entering clinical trials, and ethical considerations that some of these technologies and/or their applications provoke.

\section{Keywords}

Genome editing, investments, market, research \& development, ethics.
Beyond a certain point, there is no return. This point has to be reached.

Franz Kafka

In 2017, the global cell and gene therapy market was valued at USD 6 billion, and it is expected to grow at $21.9 \%$ annually, exceeding USD 35 billion by 2026 [1]. North America comprises about one-half of this market.

Food and Drug Administration (FDA), the US regulatory authority, admits 'a surge of cell and gene therapy products entering early development, evidenced by a large upswing in the number of investigational new drug (IND) applications' [2]. By the end of 2018, nearly 300 cell and gene therapy products had been in development for the treatment of more than 100 various diseases, mostly cancer [3]. The vast majority of these medicines are still in the early phases of clinical trials. Nevertheless, top market players are actively investing in $R \& D$ programs of cell and gene therapies. Since 2010, there have been 120 venture investments in gene therapy, with USD 5 billion raised, half of them have been disclosed since the beginning of 2018 [4]. Notably, unlike other fields of biopharmaceuticals, the vast majority of investments (over USD 3 billion) went to companies with only a platform technology or still at the preclinical stage with no clinical data available yet, showing the intensity of interest to this field.
FDA anticipates that by 2020 they will be receiving more than 200 cell-based or directly administered gene therapy IND applications annually. Current predictions based on the existing pipeline and the clinical success rates state that by 2025, FDA is expected to approve 10 to 20 novel cell and gene therapy products a year [2].

Today, many new technologies enter clinical trials, e.g., CRISPR-edited cells for cancer immunotherapy, new gene therapies for inherited and rare diseases. There's a potential to expand indications to the more prevalent diseases, including cardiovascular, neurological, endocrine disorders.

Within the last 3 years, there have been several important first-time regulatory approvals, most of them in the USA and EU. In 2017, two approvals of CAR-T products opened access to a novel autologous $\mathrm{T}$ cell immunotherapy approach for pediatric and adult patients with B-cell malignancies. Kymriah (tisagenlecleucel) was approved by the FDA and European Medicines Agency (EMA) for the treatment of refractory or relapsed B-cell precursor acute lymphoblastic leukemia in children and for relapsed/refractory large B-cell lymphoma in adults [5]. It is currently sold in the US by Novartis at the price of up to USD 475.000. With additional expenses for hospitalization and supportive care, the costs would make it up to USD 1 million per patient [6]. Yescarta (axicabtagene ciloleucel) was approved by the FDA and 
EMA for the treatment of relapsed or refractory large B-cell lymphoma in adults [7], being currently sold in the USA for USD 373.000 per unit. This product was initially developed by Kite Pharma, which was eventually acquired by Gilead for USD 11.9 billion [8].

Despite that the clinical toxicity issues, such as cytokine release syndrome and neurological toxicities have been mostly resolved, the financial toxicity of these novel therapies remains an unmet problem for patients and healthcare systems. The recent study on cost-effectiveness of CAR T cell therapy in relapsed or refractory adult large B-cell lymphoma has demonstrated that, in an optimistic scenario with a $40 \%$ 5-year progression-free survival (PFS), axicabtagene ciloleucel increased life expectancy by 8.2 years at the cost of USD 129.000/quality-adjusted life year (QALY) gained. Similarly, tisagenlecleucel, with a 35\% 5-year PFS, increased life expectancy by 4.6 years at USD 168.000 per QALY gained. If CAR-T cells will be tomorrow administered by therapeutic grounds to all the US patients, it would increase health care costs by approximately USD 10 billion over 5 years [9]. Therefore, only substantial price reductions, or alternative payment scenarios (e.g. based on initial complete response) would allow CAR $\mathrm{T}$ cell therapies to meet a less than USD 150.000/QALY threshold at more modest long-term clinical outcomes.

Manufacturing is another significant challenge in the field today. On the one hand, the FDA is working on improving appropriate guidelines, to ensure easier bridging to more efficient technologies safely and cost-effectively, without additional clinical investigations. On the other hand, the contract manufacturing organizations (CMO), i.e. of viral vectors, are being acquired by large industrial players to ensure quality control and the most efficient manufacturing process as well as to offer a wider range of the CMO services to their clients.

Among the latest approvals of gene therapies, the most disputed one was a novel Novartis drug, Zolgensma (onasemnogene abeparvovec-xioi), developed by AveXis for the treatment of pediatric patients with spinal muscular atrophy (SMA). This most expensive drug priced at USD 2.1 million caused a lot of discussions because of the unprecedented follow-up story of uncovered data inaccuracy submitted to FDA [10]. The long-term consequences of this story are yet to be expected.

Ethics around the cell and gene therapy is increasingly becoming another important element characterizing this field. The first gene-edited babies in China, followed by the statement from a Russian scientist [11] led to the worldwide attention of the scientific community and the call for a moratorium on clinical uses of germline gene editing.

In the meantime, the Nuffield Council on Bioethics published a report on the social and ethical issues raised by the use of genome editing 'as a technology that could influence inherited characteristics in humans' [12]. It concludes that "the potential use of heritable genome editing interventions to influence the characteristics of future generations could be ethically acceptable in some circumstances" as long as it is intended for the good of a person who will be born, and it does not increase disadvantage, discrimination, or division in society.
Many scientists and entrepreneurs believe that no matter how hard regulations are, technology advent cannot be stopped. However, only few patients, if any, would voluntarily agree to become a victim of unregulated research. Human history has already learned this lesson and came to the agreement to protect humanity and devote research to its welfare. The non-return point has been reached, and new technologies will definitely keep emerging. Our main task today is to make sure that the benefit-risk ratio remains positive on the patients' side.

\section{Conflict of interests}

The author has no conflicts of interest to be declared.

\section{References}

1. Cell and Gene Therapy Market. Coherent Market Insights Analysis (2018). Published Feb 2019; 164 pages.

2. Statement from FDA Commissioner Scott Gottlieb, M.D. and Peter Marks, M.D., Ph.D., Director of the Center for Biologics Evaluation and Research on new policies to advance development of safe and effective cell and gene therapies. January 15, 2019. FDA's website: https://www.fda.gov.

3. Medicines in Development for Cell Therapy and Gene Therapy. America's Biopharmaceutical Companies 2018 Report. Published on the Pharmaceutical Research and Manufacturers of America's website: https://www.phrma.org/.

4. DealForma Database. June 2019. Reported by David H. Crean on 27.06.2019. Source: https://pharmaboardroom. $\mathrm{com} /$.

5. Kymriah. FDA Prescribing Information. FDA's website: https://www.fda.gov.

6. Cavallo J. Weighing the Cost and Value of CAR T-Cell Therapy. A Roundtable Discussion With Carl H. June, MD; Sagar Lonial, MD; David G. Maloney, MD, PhD; and Pascal Touchon. ASCO Post. May 25, 2018. Website: https://www. ascopost.com/.

7. Yescarta. FDA Prescribing Information. FDA's website: https://www.fda.gov.

8. Gilead's press release on August 28, 2017. Gilead's website: https://www.gilead.com/.

9. Lin JK, Muffly LS, Spinner MA, et al. Cost Effectiveness of Chimeric Antigen Receptor T-Cell Therapy in Multiply Relapsed or Refractory Adult Large B-Cell Lymphoma. J Clin Oncol. 2019; 37(24):2105-2119.

10. FDA Statement on data accuracy issues with recently approved gene therapy. August 6, 2019. FDA website: https:// www.fda.gov.

11. David Cyranoski. Russian biologist plans more CRISPR-edited babies. Nature 570, 145-146 (2019).

12. Nuffield Council on Bioethics (2018) Genome Editing and Human Reproduction: social and ethical issues (London: Nuffield Council on Bioethics), 183 pages. 


\section{І Игра геномов: продолжение следует}

\section{Кристина А. Закурдаева}

Фонд поддержки научных исследований в онкологии (РакФонд), Москва, Россия

\section{Резюме}

За последние пять лет область редактирования генома кардинально изменилась и трансформировалась из научных идей и лабораторных исследований в многочисленные клинические применения, меняющие жизнь пациентов, новые коммерческие возможности с существенными инвестициями в области и заметными сделками и социальные дилеммы, поднимающие множество вопросов перед медицинским сообществом и широкой общественностью. Сегодня многие из самых передовых исследований и разработок, инвестиций, регуляторных инициатив и этических дискуссий происходят именно в этой области. Итак, могут ли рынок и общество идти в ногу с последними научными открытиями, и что будет дальше?
В этом эссе будут обсуждаться возможности и трудности современного рынка клеточной и генной терапии, последние одобрения и их клинические и экономические последствия, новые технологии, которые транслируются в клинические исследования, и этические вопросы, которые вызывают некоторые из этих технологий и/или их применение.

\section{Ключевые слова}

Редактирование генома, инвестиции, рынок, исследования и разработки, этика. 